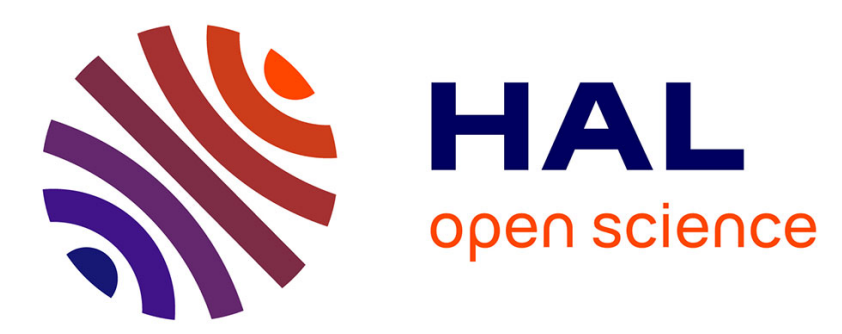

\title{
Crusting, runoff and sheet erosion on silty loamy soils at various scales and upscaling from $\mathrm{m} 2$ to small catchments
}

\author{
Yves Le Bissonnais, H. Benkhadra, V. Chaplot, Dennis Fox, D. King, J.
} Daroussin

\section{To cite this version:}

Yves Le Bissonnais, H. Benkhadra, V. Chaplot, Dennis Fox, D. King, et al.. Crusting, runoff and sheet erosion on silty loamy soils at various scales and upscaling from $\mathrm{m} 2$ to small catchments. Soil and Tillage Research, 1998, 46, pp.69 - 80. hal-02572311

\section{HAL Id: hal-02572311 \\ https://hal.science/hal-02572311}

Submitted on 6 Dec 2021

HAL is a multi-disciplinary open access archive for the deposit and dissemination of scientific research documents, whether they are published or not. The documents may come from teaching and research institutions in France or abroad, or from public or private research centers.
L'archive ouverte pluridisciplinaire HAL, est destinée au dépôt et à la diffusion de documents scientifiques de niveau recherche, publiés ou non, émanant des établissements d'enseignement et de recherche français ou étrangers, des laboratoires publics ou privés. 


\title{
Crusting, runoff and sheet erosion on silty loamy soils at various scales and upscaling from $\mathrm{m}^{2}$ to small catchments
}

\author{
Y. Le Bissonnais ${ }^{a, *}$, H. Benkhadra ${ }^{a}$, V. Chaplot ${ }^{b}$, D. Fox ${ }^{c}$, \\ D. King a , J. Daroussin ${ }^{\text {a }}$ \\ ${ }^{a}$ Institut National de la Recherche Agronomique, Service d'Etude des Sols et de la Carte Pédologique de France, Centre de Recherche \\ d'Orléans, 45160 Olivet, France \\ b Institut National de la Recherche Agronomique, Laboratoire de Science du Sol, 65, Rue de Saint Brieuc, 35042 Rennes, France \\ ' Ecole Supérieure d'Agriculture de Purpan, 75, Voie de Toec, 31076 Toulouse, France
}

Accepted 11 March 1997

\begin{abstract}
Water erosion is one of the most active processes in soil genesis and dynamics. It is also at the origin of significant environmental problems. Soil surface state is one of the most important factors for erosion risk assessment. However, it is not easy to determine the effect of this factor at a large scale. A field experiment was held in Pays de Caux (Normandy, France) in order to study and quantify crusting, runoff and sheet erosion at the cultivated field and catchment scales. We measured crust formation, runoff and erosion during two seasons on $1-\mathrm{m}^{2}, 20-\mathrm{m}^{2}$ and $500-\mathrm{m}^{2}$ experimental plots and on a small catchment. Results allow a ranking of the most important factors influencing crusting and erosion at the different scales. They also enable the development of relationships for upscaling from small plot results to the cultivated field and catchment for specific conditions. However, upscaling from plots to catchments is generally difficult and needs to take catchment spatial structures into account. We distinguish between runoff and erosion scale transfer, the latter being at the origin of specific problems that need further research to be solved.1998 Elsevier Science B.V. All rights reserved.
\end{abstract}

\section{Résumé}

L'érosion hydrique est l'un des processus les plus actifs dans la genèse et l'évolution de la couverture pédologique. Elle est aussi aujourd'hui à l'origine d'importants problèmes d'environnement. Afin de prévoir les risques et d'estimer les zones sensibles, il est nécessaire d'étudier l'influence de la dynamique structurale superficielle des sols et des pratiques culturales sur la genèse du ruissellement et de l'érosion diffuse. Il est également important de pouvoir évaluer la signification à différentes échelles des mesures réalisées à une échelle donnée et les possibilités d'extrapolation spatiale des mesures réalisées sur des petites parcelles expérimentales. On présentera ici quelques résultats préliminaires d'une expérience réalisée dans le Pays de Caux visant à analyser le déterminisme et à quantifier le ruissellement et l'érosion diffuse à différentes échelles dans un milieu agricole. Les mesures ont été effectuées au printemps pour des parcelles en jachères nues ou semées et en hiver sur des céréales. On compare les valeurs de ruissellement et de charge solide obtenues sur des parcelles expérimentales de $1 \mathrm{~m}^{2}, 20 \mathrm{~m}^{2}$ et $500 \mathrm{~m}^{2}$, ainsi que des mesures effectuées aux exutoires de petits bassins versants élémentaires. Les résultats permettent, d'une part, d'identifier et de hiérarchiser les mécanismes et facteurs déterminants du

\footnotetext{
" Corresponding author. E-mail: lebisson@orleans.inra.fr
} 
ruissellement et de l'érosion diffuse, et d'autre part, d'établir quelques relations pour le transfert d'échelle des processus étudiés depuis le $\mathrm{m}^{2}$ jusqu'au bassin versant élémentaire agricole. đ 1998 Elsevier Science B.V. All rights reserved.

Keywords: Crusting; Runoff; Sheet erosion; Upscaling; Field experiment; Catchment

Keywords: Battance; Ruissellement; Erosion diffuse; Changement d'échelle; Expérimentation au champ; Bassin versant

\section{Introduction}

In the northwestern Paris basin and in many cultivated areas of the loessian belt in northern Europe, soil erosion is a frequent problem because of the soil susceptibility to crusting and the evolution of cultivation systems that reduce the vegetation cover (Monnier et al., 1986; Papy and Douyer, 1991). Clod disaggregation under raindrop impact results in the formation of surface crusts and in the reduction of depressional storage that in turn increase the runoff and subsequent erosion risk (Farres, 1987; Boiffin et al., 1988; King and Le Bissonnais, 1992). Sheet erosion as well as ephemeral rill and gully erosion occur under frequent low-intensity winter rains and during spring and summer storms. Both types of erosion cause on-site and off-site problems. Although concentrated erosion is the most apparent and has been studied preferentially (Auzet et al., 1992, 1995), sheet or interrill erosion is also significant and may be more threatening to the environment. Water quality may be affected in particular by transported pesticides and other agrochemicals applied to the soil surface.

The assessment of runoff and crosion risks is generally based on measurements from small experimental plots or from catchment outlets. Process analysis and spatial extrapolation are difficult with these types of data (Thebe, 1987; De Boer and Campbell, 1989): plots are too small and may not be representative of soil variability and of some processes (Abrahams et al., 1991; Govers, 1991; Mathier and Roy, 1996); catchments are often treated as black boxes and interpretation of measurements in terms of mechanisms is difficult. In addition, replicates are generally not available. The cultivated field scale, which is the elementary spatial unit for soil surface conditions (crusting) and vegetation cover, is rarely taken into account.

The aim of this study is to analyze the erosion parameters and mechanisms and to quantify runoff and sheet erosion at different scales within a small cultivated catchment. Measurements were made during winter and spring on experimental plots of $1 \mathrm{~m}^{2}$, $20 \mathrm{~m}^{2}$ and $500 \mathrm{~m}^{2}$, and at the outlet of a small catchment (70 ha). We also wish to discuss the possibilities of upscaling from plot measurements to small agricultural catchments.

\section{Materials and methods}

The experiment was carried out in the Blosseville catchment located in the northwest part of the Paris basin (Pays de Caux). The area is covered by silty loamy soils: Luvisols developed on the loess quaternary deposit and containing a least $60 \%$ silt in the surface horizons. These soils are very prone to soil crusting because of the low clay content (13 to 17\%) and low organic-matter content (1 to $2 \%$ ). The topography is relatively smooth with slope gradients ranging between 1 to $4 \%$ on the plateau and 4 to $10 \%$ on valley sides.

The soil characteristics showed very little variability within the studied catchment and areas with slope gradients greater than 5\% accounted for less than $10 \%$ of the total catchment area. The size of cultivated ficlds ranged between 1 and 10 ha (Fig. 1). They were connected without hedges or ditches separating contiguous fields, allowing large volumes of water generated on bare, crusted soils (up to $50 \%$ of rain amount) to concentrate and erode fields. This runoff and erosion processes occurred during winter although rainfall intensities are generally moderate (1 to $10 \mathrm{~mm} \mathrm{~h}^{-1}$ for $80 \%$ of the rain amount).

Measurements were made during spring and early summer 1994 and during winter 1995. Both years received more than average rainfall amounts which are about $800 \mathrm{~mm} \mathrm{yr}^{-1}$. The experimental field length was about $100 \mathrm{~m}$ located in the middle of a convexo-concave catena and with slope gradients of 


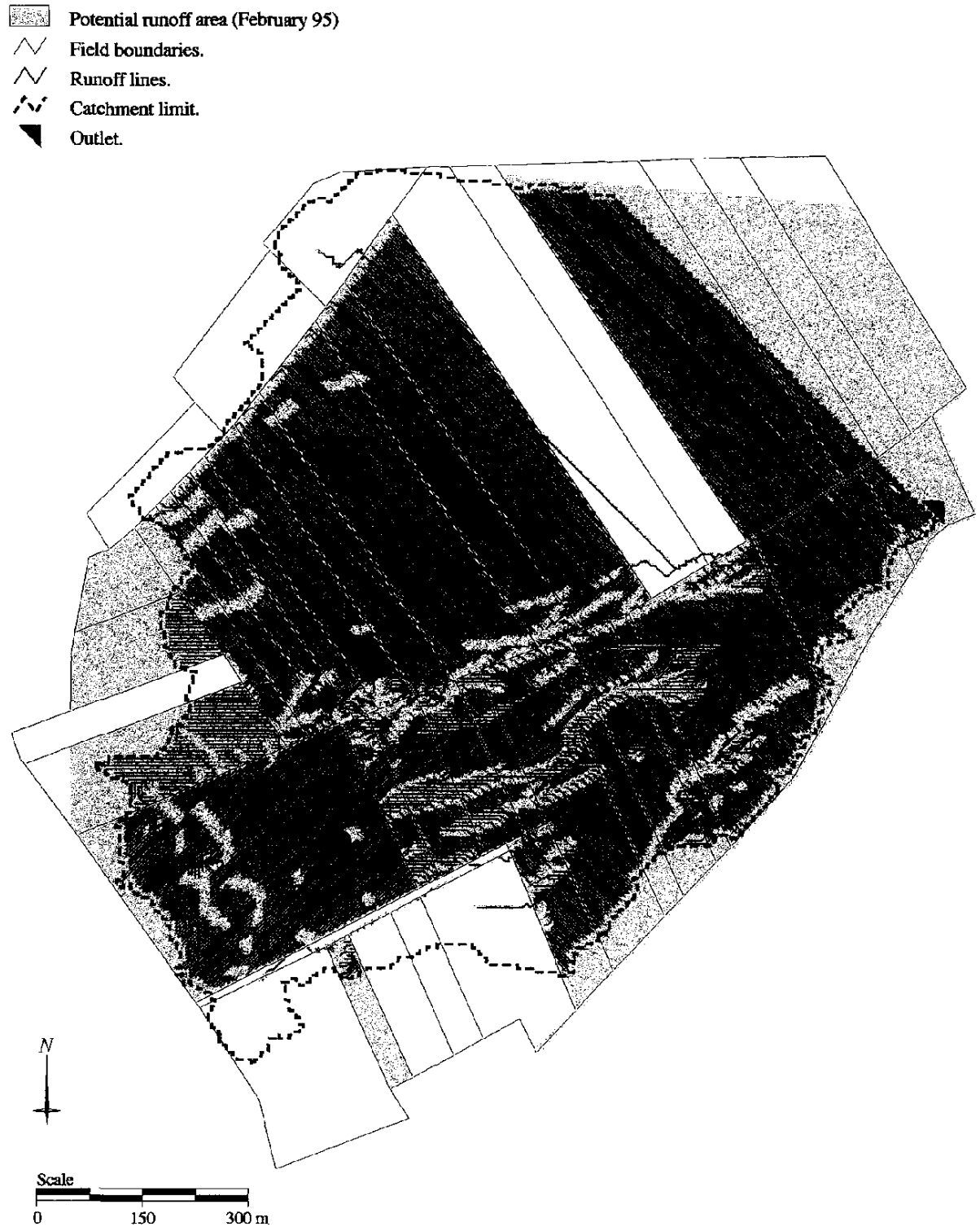

Fig. 1. Map of the Blosseville catchment showing the field boundaries, the potential runoff areas determined as the bare and crusted surfaces at the date of observation and the runoff lines which are calculated from a digital elevation model using the grid module of Arcinfo software (ESRI, 1992; Souchère, 1995).

about $2 \%, 4 \%$ and $8 \%$ from the top to the bottom. Three $1 \times 1-\mathrm{m}^{2}$ plots and two additional $2 \times 10-\mathrm{m}^{2}$ plots were present for each position and the two $500-\mathrm{m}^{2}$ plots $(62.5 \mathrm{~m}$ long by $8 \mathrm{~m}$ wide) were located at the intermediate position ( $4 \%$ slope). The plots and cultivation direction were oriented parallel to the main slope of the field. Results for the inter- mediate position will be presented here. Runoff was collected at the bottom end of the plots by means of a gutter connected to reservoirs. Runoff volumes in the reservoirs were measured after each rainfall event and runoff coefficients (ratio between rainfall amount and runoff amount) were calculated for each plot and each rainfall event. Aliquot samples were collected 
in the reservoirs for the calculation of average sediment concentrations by weighing after oven drying the collected samples at $105^{\circ} \mathrm{C}$.

The outlet of the catchment was equipped with a calibrated flume and an automatic water-level gauge allowing continuous runoff output measurement. Sediment sampling was made by hand during the rainfall events.

For the spring experiment, the plots were tilled, prepared for sowing and either sowed with a ray grass/clover blend the 25th of April or kept unsowed for the season. For the winter experiment the plots were tilled and cultivated with winter wheat sowed late in September, so the rate of soil coverage was less than $10 \%$ of the surface during winter until March. Only $10 \%$ of the catchment area was occupied by permanent pasture and the rest was cultivated with about $50 \%$ of winter cereals and $50 \%$ of spring crops, the latter remaining either ploughed, stubble-ploughed or nontilled during winter.

In addition to rainfall monitoring, the surface states and vegetation cover were observed twice a month during the period of study. Particularly, surface roughness, soil-crusting stages and rate of soil coverage by vegetation were measured semiquantita- tively according to the scoring proposed by Boiffin et al. (1988) and Bresson and Boiffin (1990). Three main stages of crusting were distinguished: initial fragmentary stage (F0), structural crust (F1) and sedimentary crust (F2).

\section{Results}

Two types of results will be presented in this paper. One for a series of storm events leading to erosion during the spring-summer season, illustrating the effect of vegetation cover, and the second for a winter rain showing the effect of rainfall intensity on bare soils (sowed with winter wheat).

\subsection{Rainfall characteristics}

Daily rainfall amount and cumulative rainfall from the beginning of the experiment for the spring summer season 1994 are presented in Fig. 2. May and July were relatively wet ( 89 and $136 \mathrm{~mm}$ ), and June was rather dry $(29 \mathrm{~mm})$. Three heavy rainstorms (rain $>20 \mathrm{~mm}$ with intensities between 5 and $8 \mathrm{~mm} \mathrm{~h}^{-1}$ ) occurred which had a three-year return time. The maximal 4 -min rainfall intensity

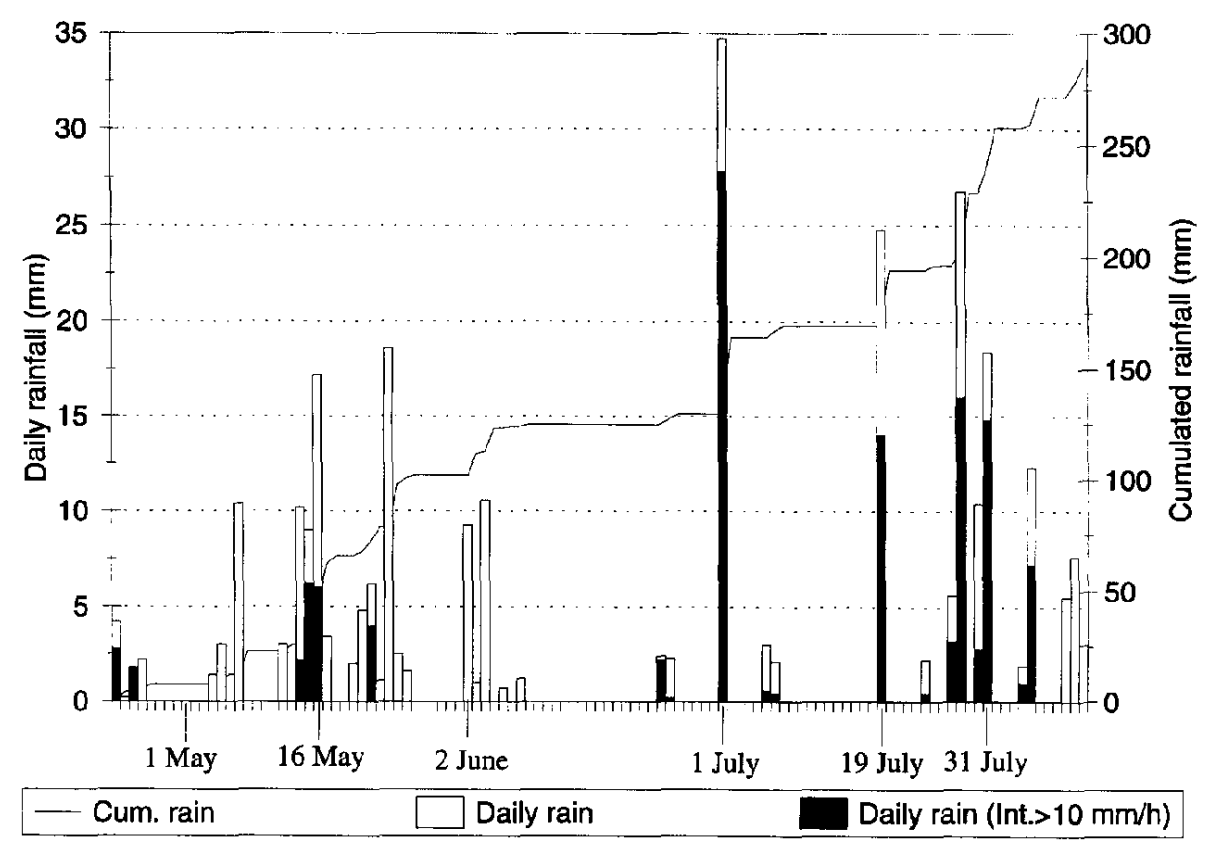

Fig. 2. Rainfall characteristics for spring-summer 1994. Daily rain amount (histogram), and cumulative rainfall (line). Note that June was dry, May and July wet with three heavy rainstorms in July. 


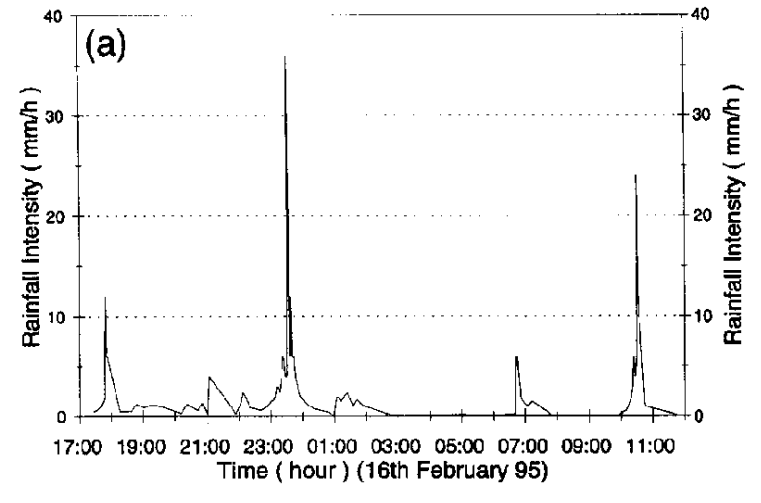

Rainfall Intensity $(\mathrm{mm} / \mathrm{h})$

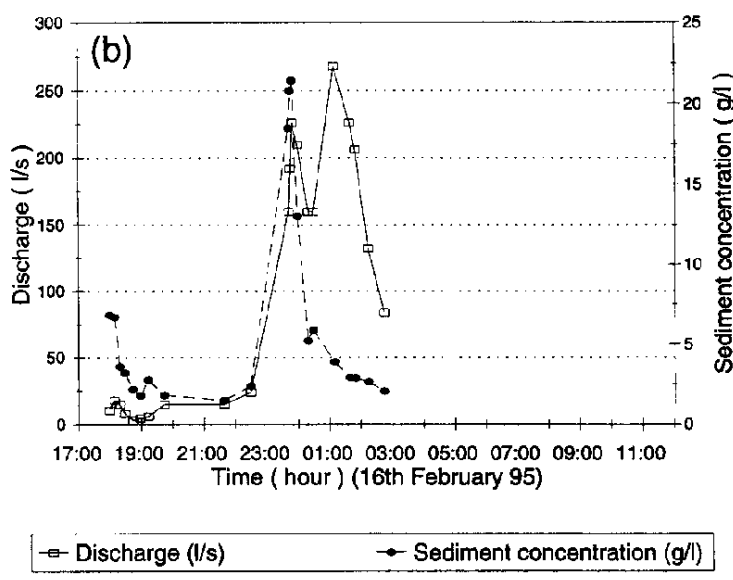

Fig. 3. Rainfall intensity (a), nunoff amount and sediment concentration (b) for the rain of February 16, 1995.

was calculated for each of these events and four selected rainfall events from this period will be presented here (May 17, July 1, July 19 and August 12).

The winter 1995 event dated February $16-17$ was divided into three periods of different rainfall intensities. The total rainfall amount for this event was 16 mm (Fig. 3a). It corresponds to a representative event for the winter season.

\subsection{Surface conditions}

Crusting development and surface cover evolution for spring-summer 1994 are showed in Fig. 4. Initial surface conditions were the same for all plots (seedbed). The crust formation and roughness de- crease were the same for both sowed and unsowed plots until the emergence and growth of vegetation. On May 30, the plots received approximately 100 $\mathrm{mm}$ of cumulative rainfall and the structural crust was well formed, with the beginning of the formation of sedimentary crust. This rapid surface degradation is related to the low aggregate stability of the soil (Le Bissonnais and Bruand, 1993). After this date the two types of plots varied in plant cover and therefore in crust development. The sedimentary crust continued to develop in surface area and in thickness on bare plots, whereas its evolution was limited on covered plots.

For the winter 1995 season the initial surface condition was also a seedbed. The surface received $450 \mathrm{~mm}$ of cumulative rain until the date of the event presented here (February 16-17). The surface was therefore completely degraded during this event, with a sedimentary crust covering almost the whole surface. The rate of vegetation cover was less than $10 \%$.

\subsection{Runoff coefficients}

\subsubsection{Spring-summer 1994}

The first event producing runoff on $20 \mathrm{~m}^{2}$ plots occurred three weeks after sowing with only 25.6 $\mathrm{mm}$ of cumulative rainfall. Afterwards every rain with more than $1 \mathrm{~mm} \mathrm{~h}^{-1}$ intensity produced runoff except during the dry period of June. Runoff occurred either during low-intensity long rainfall (May

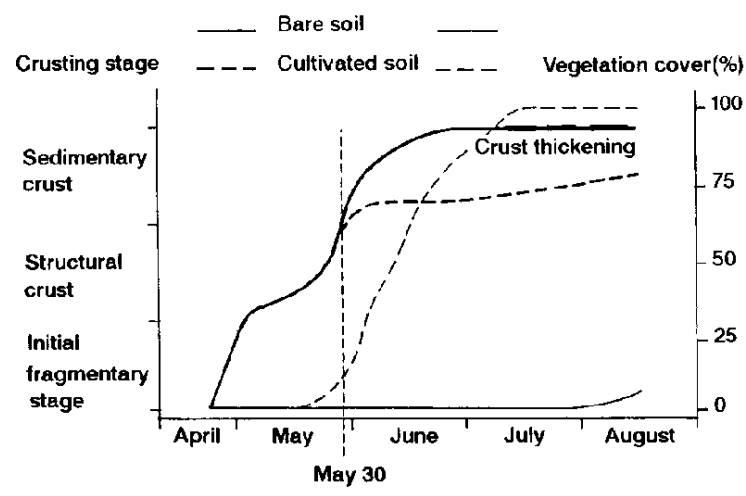

Fig. 4. Evolution of soil-surface crusting and surface-cover rates for the experimental plots during the spring-summer 1994 season. Before May 30 the plot surface conditions were the same; after this date they differed in plant cover and crust development. 


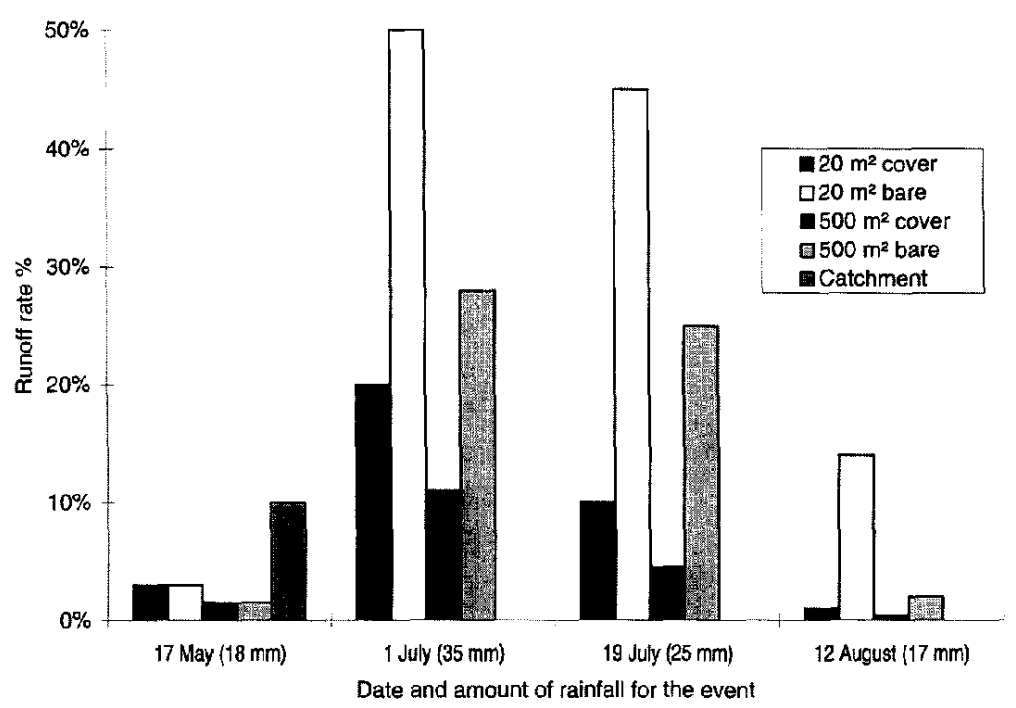

Fig. 5. Runoff coefficients at different scales for selected rain events during spring-summer 1994.

25) or during rainstorms with high intensities and varying duration (July).

The event of May 17 occurred before vegetation emergence and surface roughness and crusting stage were similar for both types of plots (Fig. 4). Runoff coefficients on $20 \mathrm{~m}^{2}$ plots were around $3 \%$ (Fig. 5). However, large differences between bare and covered plots were observed after July 1 (cumulative rainfall $=129.7 \mathrm{~mm}$, vegetation cover $>95 \%$ ). Vegetation development reduced runoff but the lack of rain during June prevented estimation of the threshold of vegetation cover that affects runoff. Differences in runoff coefficients between bare and covered plots increased with rainfall intensity (Fig. 5). The runoff coefficients for the $500 \mathrm{~m}^{2}$ plots followed the same trend but they were about $50 \%$ lower than those measured on $20 \mathrm{~m}^{2}$ (Fig. 5).

These results can be related to the evolution of the soil surface state which depends on rainfall conditions and plant growth (Le Bissonnais et al., 1995).

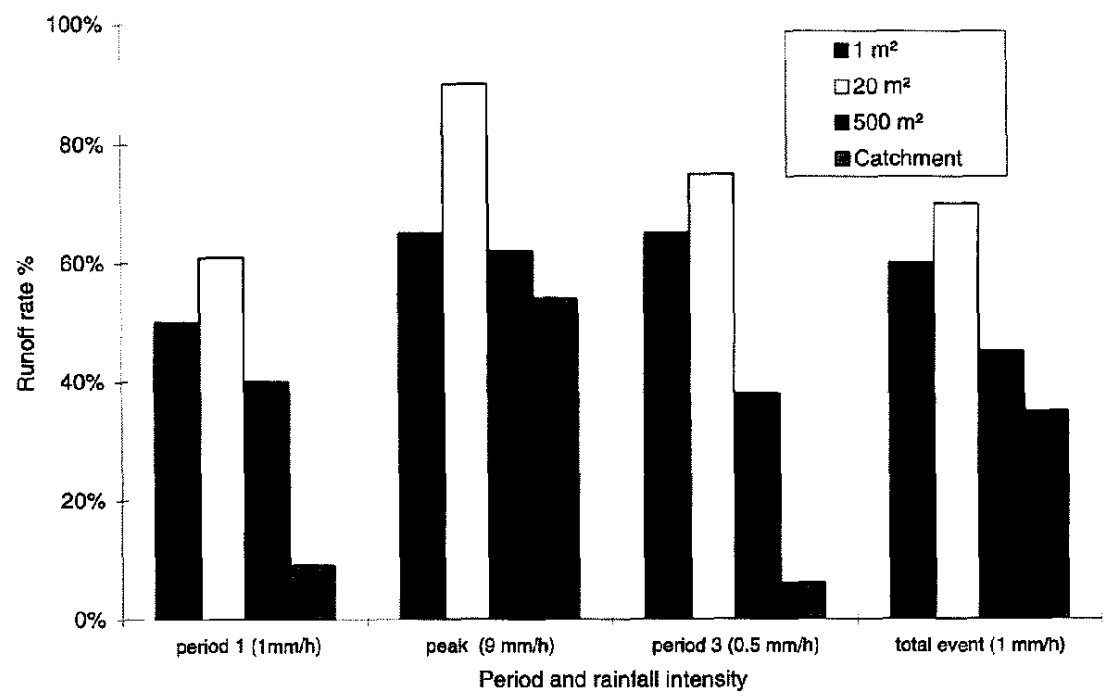

Fig. 6. Runoff coefficients at different scales for the three periods of the rain of February 16, 1995. 
Starting from similar initial states of small clods and aggregates, the surfaces of the various plots form similar crusts as long as the amount of vegetation cover is not sufficient to protect the soil surface against further degradation. During our experiment this protection by vegetation seems to be effective after May 30 (Fig. 4). After this period, the surface of the plots with vegetation corresponds to a structural crust with some residual clods (Bresson and Boiffin, 1990) and it does not change much until the end of the experiment. On the other hand, bare plots become completely smooth by the end of the season, and have a thick sedimentary crust $(>1 \mathrm{~cm})$.

At the catchment scale, we have one data point for May 17 showing a runoff coefficient greater than for the experimental plots $(10 \%)$. This is because more than $80 \%$ of the catchment area corresponds to cultivated fields with a surface state much more degraded than the experimental plots (potential runoff areas shown in Fig. 1), due to early cultivation (winter wheat). In addition, all of these fields are directly connected without obstacles to runoff from the top to the outlet of the catchment (runoff lines shown in Fig. 1). We have no runoff data available at catchment scale for the two July events due to technical problems, although we know that runoff occurred. No runoff was measured at the outlet for the August 12 event.

\subsubsection{Winter 1995}

The soil surface of the plots was bare. It was much more crusted by February 17 after $400 \mathrm{~mm}$ of cumulative rain than during spring 1994. Runoff coefficients were $>50 \%$ for the peak period for all scale measurements (Fig. 6). Runoff started just after the rain intensity reached 2 to $5 \mathrm{~mm} \mathrm{~h}^{-1}$ for the plots as well as for the catchment (Fig. 3b). The 1 $\mathrm{m}^{2}$ measurements showed runoff coefficients slightly lower than for the larger plots. At the basin scale, the runoff coefficients increased from $10 \%$ to $50 \%$ for intensities of 1 and $9 \mathrm{~mm} \mathrm{~h}^{-1}$, respectively.

\subsection{Sediment concentration}

\subsubsection{Spring-summer 1994}

Results for sediment concentration are similar for $20 \mathrm{~m}^{2}$ and $500 \mathrm{~m}^{2}$ plots (Fig. 7). Samples from bare soils under high rainfall intensity ( $I_{\max }$ for $4 \mathrm{~min}=$ $50 \mathrm{~mm} \mathrm{~h}^{-1}$ ) showed values between 25 and $50 \mathrm{~g} \mathrm{l}^{-1}$ (May 17). The influence of vegetation cover appears only in July, 2 months after sowing. We measured very high sediment concentration for the bare plots: $100 \mathrm{~g} \mathrm{l}^{-1}$ for the July 1 event with $I_{\max }$ for $4 \mathrm{~min}$ $>50 \mathrm{~mm} \mathrm{~h}^{-1}$. Sediment concentration then decreased with rainfall intensity $\left(14 \mathrm{~g} \mathrm{l}^{-1}\right.$ August 12 , with $I_{\max }$ on $4 \mathrm{~min}=25 \mathrm{~mm} \mathrm{~h}^{-1}$ ). Sediment concentration under vegetation was 10 to 30 times smaller for all intensities.

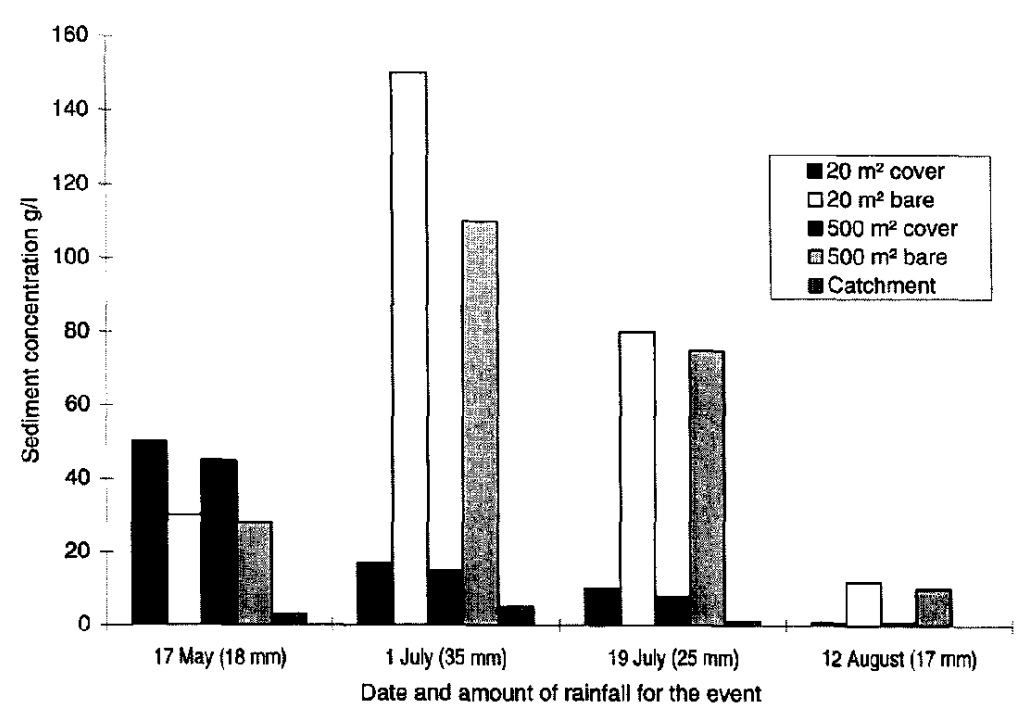

Fig. 7. Sediment concentration at different scales for selected rain events during spring-summer 1994. 
At the catchment outlet, sediment concentration was always low compared to the plot measurements. This decrease in sediment concentration between plots and outlet may be due to channel deposition and to reduced transport capacity of the flow at the lower concave part of the catchment. However, the variations in slope steepness along the main runoff concentration line within the catchment are small. Another hypothesis for this reduction of sediment concentration could be related to dynamics of the process: runoff at the outlet lags behind rainfall and runoff often continues after rainfall ceases. Therefore, raindrop impact, which is the main agent responsible for sediment detachment and transport (Proffitt et al., 1991), is no longer efficient and the sediment concentration decreases. Experimental results from the same area showed that sediment concentration in sheet runoff can be reduced to one third without raindrop impact for a runoff velocity of $\mathbf{1 5}$ $\mathrm{cm} \mathrm{s}^{-1}$ (Chaplot and Le Bissonnais, 1998).

\subsubsection{Winter 1995}

Sediment concentration was about $20 \mathrm{~g}^{-1}$ for the $20-\mathrm{m}^{2}$ and $500-\mathrm{m}^{2}$ plots and the average value at the catchment outlet was about $5 \mathrm{~g} \mathrm{l}^{-1}$ during the February 16-17 event (Fig. 8). The hypothesis to account for this difference in sediment-concentration results between catchment and plots is the same as for the spring period. However, the difference be tween scales is small. This could be related to the fact that rain events are longer and of lower intensity in the winter compared to spring-summer rainstorms. In addition, Fig. 3 b shows that the maximal value of sediment concentration during the runoff peak of the event was about $20 \mathrm{~g} \mathrm{l}^{-1}$, which is the value measured on the $20-\mathrm{m}^{2}$ and $500-\mathrm{m}^{2}$ plots. This result shows that, with specific rainfall conditions and during a short period of time within the rain event, the catchment may behave as a large plot.

Measurements on the $1 \mathrm{~m}^{2}$ plots show that sediment concentration is about half that of the $20-\mathrm{m}^{2}$ and $500-\mathrm{m}^{2}$ plots with about the same runoff amount (Figs. 6 and 8). This is due to the reduced length of the plot which does not allow the flow velocity to be sufficiently high for sediment transport (Fig. 7) (Chaplot and Le Bissonnais, 1998).

Results also show the close relationship between sediment concentration and rainfall intensity: sediment concentration is five times higher for the period with an average intensity of $9 \mathrm{~mm} \mathrm{~h}^{-1}$ compared to the period with $1 \mathrm{~mm} \mathrm{~h}^{-1}$. At the basin scale the response is smoother, probably because of short-term variations in rainfall intensity. The spatial variability of rainfall intensity at the catchment scale was not monitored, but it certainly exists. It is also possible that at the catchment scale the sediment concentra-

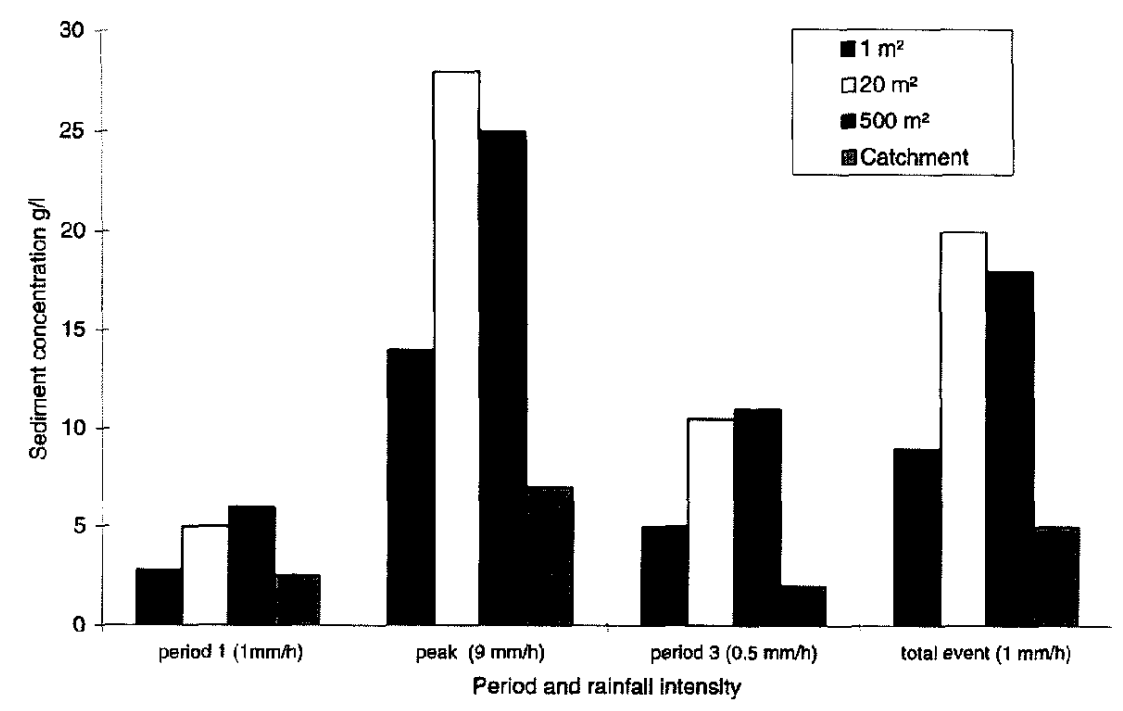

Fig. 8. Sediment concentration at different scales for the three periods of the rain of February 16, 1995. 


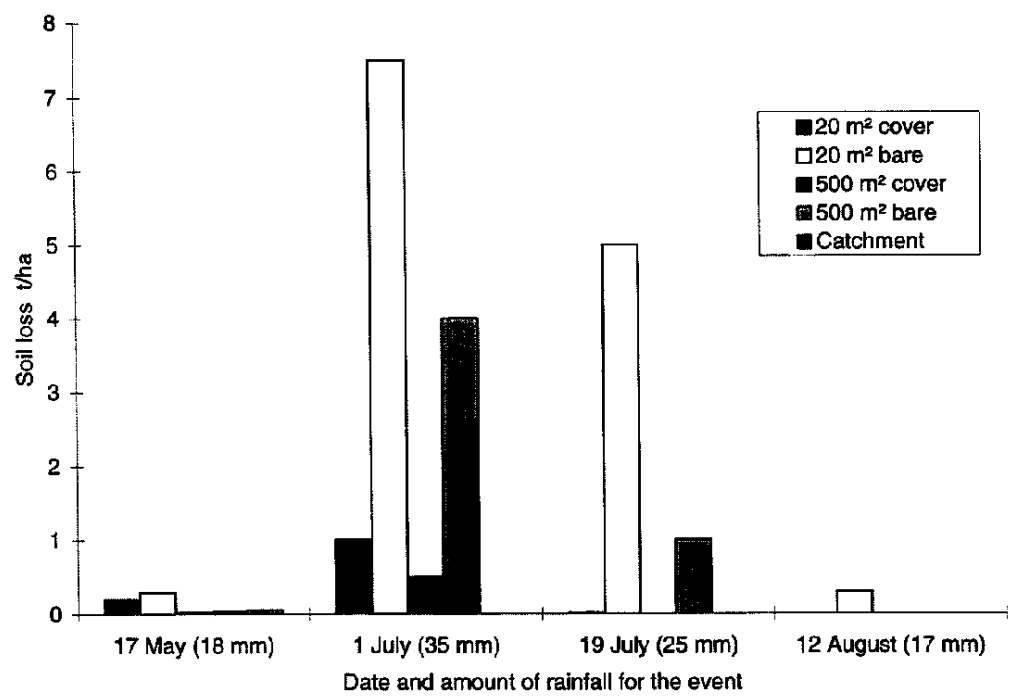

Fig. 9. Soil loss at different scales for selected rain events during spring-summer 1994. Note the effect of vegetation cover from July.

tion is controlled more by runoff velocity than by rainfall intensity, and therefore it depends on catchment morphology. This is confirmed by the close relationship between sediment concentration and discharge (Fig. 3b).

\subsection{Sediment loss}

The product of runoff volume times the sediment concentration gives sediment loss at different scales
(Figs. 9 and 10). For the $500-\mathrm{m}^{2}$ plots, sediment loss calculated for the July 1 event is about $4 \mathrm{t} \mathrm{ha}^{-1}$. Unfortunately we have no runoff measurements for this event at the catchment scale, so we can only estimate, on the basis of a 0.25 scale ratio calculated for other events during the same season (not presented here), that the order of magnitude of soil loss for the catchment is about $1 \mathrm{t} \mathrm{h}^{-1}$.

For the winter event, data give losses of $2 \mathrm{t} \mathrm{ha}^{-1}$

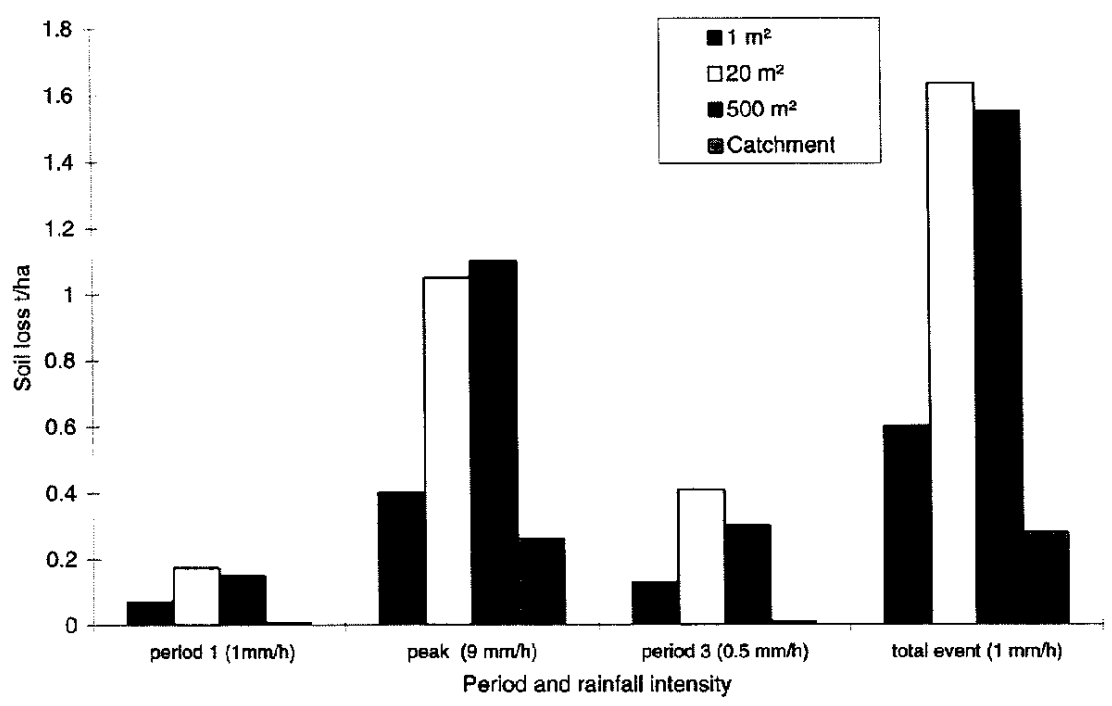

Fig. 10. Soil loss at different scales for the three periods of the rain of February 16-17, 1995. 


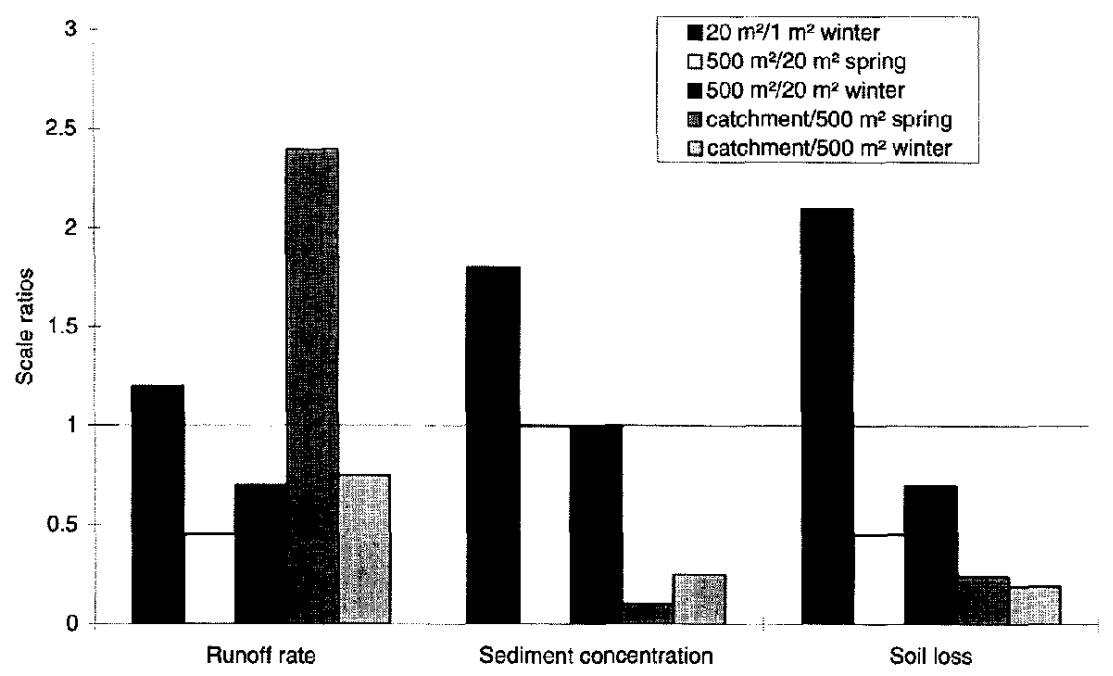

Fig. 11. Scale ratios for runoff coefficient, sediment concentration and soil loss for 1994 and 1995.

for the plots and $0.3 \mathrm{t} \mathrm{ha}^{-1}$ for the catchment with $90 \%$ of the soil loss occurring during the runoff peak period.

These results show that sheet erosion may be quantitatively more important than previously reported for the context of this experiment by comparison with linear erosion (Auzet et al., 1995). They also provide an explanation for the rapid filling by sediments of small reservoirs which are installed in order to protect urban areas against muddy floods (Fauck, 1994).

\section{Discussion of scale transfer}

Results prompt us to start a discussion about various aspects of scale transfer, upscaling runoff and erosion measurements from $1 \mathrm{~m}^{2}$ to catchment scale (Lebel, 1990;Mannaerts, 1992).

\subsection{Comparisons $20 \mathrm{~m}^{2} / 1 \mathrm{~m}^{2}$}

The discussion about $1 \mathrm{~m}^{2}$ to $20 \mathrm{~m}^{2}$ scale transfer is mainly a methodological question: both plot sizes concern local measurements and the problem is to determine the minimal plot size which allows the elementary processes of erosion to occur and to evaluate the minimal area representative of a given field surface state. Our results (Fig. 11) show a scale ratio for runoff slightly above 1 , which could be due to leakage at $1-\mathrm{m}^{2}$ plot borders. The scale ratio for sediment concentration is about 2 , which is certainly related to the limited flow velocity and transport capacity for the 1-m length. Soil loss therefore appears to be underestimated at $1 \mathrm{~m}^{2}$ compared to 20 $\mathrm{m}^{2}$, despite similar surface conditions. This limitation for the extrapolation of small-plot erosion measurements to larger surfaces has been previously noted by various authors (Govers, 1991; Mannaerts, 1992; Mathier and Roy, 1996). However, Mathier and Roy (1996) showed that a relation between sediment and water discharge calibrated for a smallscale plot could be used on a larger scale field.

\subsection{Comparisons $500 \mathrm{~m}^{2} / 20 \mathrm{~m}^{2}$}

The objective here is to compare small plot measurements with those of larger plots whose behaviour is assumed to be representative of field behaviour, in order to estimate what scale transfer coefficients to employ when using plots to assess field behaviour. Our results show that runoff is overestimated on 20 $\mathrm{m}^{2}$ compared to $500 \mathrm{~m}^{2}$. The calculated ratios ranged between 0.4 and 0.7 with an average of 0.5 (Fig. 11). In accordance with Dunne et al. (1991), we can relate this scale factor to microtopography and plot length: with increasing length, the runoff flow depth increases due to accumulated upslope runoff, and a 
larger part of the surface is submerged. Mounds and cloddy areas generally have a higher porosity and infiltration capacity than the crusted areas located in depressions, so infiltration rate for a given surface unit increases. Another reason for this scale effect is the increasing probability of the presence of a preferential infiltration route (cracks or macropores) with increasing plot size. All of these effects may be variable depending on the slope steepness (Govers, 1991).

The sediment concentration does not appear to be related to plot size, and the average scale ratio between 500 and $20 \mathrm{~m}^{2}$ is close to 1 . Thus, with the hypothesis that the $500 \mathrm{~m}^{2}$ plot is representative of the cultivated field, the soil loss measurement at field scale is about half of what is measured with $20 \mathrm{~m}^{2}$ plots because of runoff overestimation on the lattersize plots.

\subsection{Comparisons basin $/ 500 \mathrm{~m}^{2}$}

This corresponds stricto sensu to scale transfer. Five-hundred-square-meter plots which are relatively homogeneous spatial units, representative of what could be called hydrological response units, are compared with a spatial unit of a different nature and of greater heterogeneity (Fliigel, 1995). Other processes take place on the catchment, such as runoff circulation in waterways, sediment deposition in flats and depressions etc. Scale transfer is therefore delicate and should be approached with a spatial and temporal point of view, as the processes' time scale changes with the spatial scale (De Boer and Campbell, 1989; Blöschl and Sivapalan, 1995; Blöschl et al., 1995). Runoff response on plots is almost instantaneous and it may be delayed for hours on large catchments. However, for the catchment studied here, whose surface conditions may be largely homogeneous particularly during the winter season (Fig. 1), the runoff response for the catchment does not greatly differ from the 500- $\mathrm{m}^{2}$-plot runoff response at least for the peak period (Fig. 6). The result is different during the spring period because of a greater heterogeneity in surface conditions at the catchment scale. It would be informative to get runoff references from different plots representative of the various surface conditions and to use a model accounting for the spatial interactions between hydrological response units at the catchment scale (Flügel, 1995). In any case, the response in sediment concentration, always varies between plot and catchment scales and it is necessary, for erosion modelling, to take spatial effects into account in transferring results from plot scale to catchment scale.

\section{Conclusion}

The preliminary results call for some comments.

- For the runoff coefficients, the scale ratios are highly variable and are very dependent on surface state conditions and spatial variability. However, it seems that in the context of our study, a large proportion of runoff produced on a cultivated field scale reaches the catchment outlet. Therefore, runoff measurements from plots with surface conditions representative of the main types of surfaces existing within the catchment could be useful for the prediction of runoff at the catchment outlet under specific conditions. This hypothesis remains to be tested for other catchments and conditions because the scale transfer parameters are probably specific for each situation.

- For sediment concentration, the scale ratio between plots and catchments is systematically below 1 due to sediment deposition along the route from field to catchment outlet. This deposition may result from topographic factors or from entrapment by surface cover that reduces transport capacity.

Although important work has been done during the past few years concerning scale issues and scaletransfer problems for hydrology modelling, the need for further research in the field of erosion and sediment transport at various scales is evident.

Two complementary approaches can be suggested (Blöschl and Sivapalan, 1995). The first approach is process- and model-oriented and focuses on the scaling of state variables and process parameters. The second attempts to simplify the complexity of the processes using similarity concepts.

Catchment scale erosion research in France pointed out the interest of the parameter called potential runoff contributing area, which is closely dependent upon surface conditions and corresponds to the proportion of a catchment covered by bare and crusted soil (Auzet et al., 1992, 1995; King and Le 
Bissonnais, 1992). Our results confirm the paramount importance of the surface condition in both runoff and erosion processes.

\section{References}

Abrahams, A.D., Parsons, A.J., Luk, S.H., 1991. The effect of spatial variability in overland flow on the downslope pattern of soil loss on a semiarid hillslope, southern Arizona. Catena $18,255-270$.

Auzet, A.V., Boiffin, J., Papy, F., Ludwig, B., Maucorps, I., 1992. Rill erosion as a function of the characteristics of cultivated catchments in the North of France. Catena 20 , 41-62.

Auzet, A.V., Boiffin, J., Ludwig, B., 1995. Concentrated flow erosion in cultivated catchments: influence of soil surface state. Earth Surf. Processes Landforms 20, 759-767.

Blöschl, G., Sivapalan, M., 1995. Scale issues in hydrological modelling: a review. Hydrological Processes 9, 251-290.

Blöschl, G., Grayson, R.B., Sivapalan, M., 1995. On the representative elementary area (REA) concept and its utility for distributed rainfall-runoff modelling. Hydrological Processes 9 , $313-330$.

Boiffin, J., Papy, F., Eimberck, M., 1988. Influence des systèmes de cultures sur les risques d'érosion par ruissellement concentré: I. Analyse des conditions de déclenchement de l'érosion. Agronomie 8, 663-673.

Bresson, L.-M., Boiffin, J., 1990. Morphological characterization of soil crust development stages on an experimental field. Geoderma 47, 301-325.

Chaplot, V., Le Bissonnais, Y., 1998. Slope angle effect on interrill erosion: field measurements and processes analysis. Earth Surf. Processes Landforms, submitted.

De Boer, Campbell, 1989. Spatial scale dependence of sediment dynamics in a semi-arid badland drainage basin. Catena 16 , 277-290.

Dunne, T., Zhang, W., Aubry, B.F., 1991. Effects of rainfall, vegetation and microtopography on infiltration and runoff. Water Resour. Res. 27, 2271-2285.

ESRI, 1992. Understanding GIS, the Arc/Info method. Environmental Systems Research Institute, Redlands, CA, USA.

Farres, P.J., 1987. The dynamics of rainsplash erosion and the role of soil aggregate stability. Catena 14, 119-130.
Fauck, R., 1994. Gestion de la ressource en eau. Le problème de l'érosion des terres. C.R. Acad. Agric. France 80, 3-14.

Flügel, W.A., 1995. Delineating hydrological response units by geographical information system analysis for regional hydrological modelling using PRMS/MMS in the drainage basin of the river Bröl, Germany. Hydrological Processes 9, 423-436.

Govers, G., 1991. A field study on topographical and topsoil effects on runoff generation. Catena 18, 91-111.

King, D., Le Bissonnais, Y., 1992. Rôle des sols et des pratiques culturales dans l'infiltration et l'écoulement des eaux. Exemple du ruissellement et de l'érosion sur les plateaux limoneux du nord de l'Europe. C.R. Acad. Agric. 78, 91-105.

Lebel, T., 1990. Le transfert d'ćchelle en hydrolgic: concept ou confusion? In: SEMINFOR 4 'Le transfert d'échelle'; Ed: ORSTOM, Paris, 1990

Le Bissonnais, Y., Bruand, A., 1993. Crust micromorphology and runoff generation on silty soil materials during different seasons. Catena 24, 1-16, Suppl.

Le Bissonnais, Y., Renaux, B., Delouche, H., 1995. Interactions between soil properties and moisture content in crust formation, runoff and interrill erosion from tilled loess soils. Catena $25,33-46$.

Mannaerts, C., 1992. Assessment of the transferability of laboratory rainfall-runoff and rainfall-soil loss relationships to field and catchment scales. ITC publication no. 19, Enschede, the Netherlands, $202 \mathrm{pp}$.

Mathier, L., Roy, A.G., 1996. A study of the effect of spatial scale on the parameters of a sediment transport equation for sheetwash. Catena 26, 161-169.

Monnier, G., Boiffin, J., Papy, F., 1986. Réflexion sur l'érosion hydrique en conditions climatiques et topographiques modérées: cas des systèmes de grande culture de l'Europe de l'Ouest. Cahiers ORSTOM, Série Pédologie, Vol. XXII, pp. 123-131.

Papy, F., Douyer, C., 1991. Influence des états de surface du territoire agricole sur le déclenchement des inondations catastrophiques. Agronomie 11, 201-215.

Proffitt, A.P.B., Rose, C.W., Hairsine, P.B., 1991. Rainfall detachment and deposition: experiments with low slopes and significant water depths. Soil Sci. Soc. Am. J. 55, 325-332.

Souchère, V., 1995. Modélisation spatiale du ruissellement à des fins d'aménagement contre l'érosion des thalwegs. Application à des petits bassins versants du Pays de Caux, Haute Normandie. Thèse INA-Paris Grignon.

Thebe, B.. 1987. Hydrodynamique de quelques sols du Nord Cameroun, bassins versants de Mouda, contribution à l'étude des transferts d'échelles. Thèse USTL Montpellier. 